\title{
PERBAIKAN PRODUKSI BENIH IKAN BETUTU DENGAN MANAJEMEN PEMBERIAN PAKAN ALAMI YANG DIPERKAYA GIZINYA
}

\author{
Zafril Imran Azwar, Dewi Puspaningsih, dan Imam Taufik
}

Balai Riset Perikanan Budidaya Air Tawar

Jl. Raya Sempur No.1, Bogor 16154

E-mail: zafril_ia@yahoo.com

(Naskah diterima: 9 September 2009; Disetujui publikasi: 22 Maret 2010)

\begin{abstract}
ABSTRAK
Empat perbedaan pemberian kombinasi pakan yaitu pakan alami (Moina sp. dan nauplii Artemia), serta Moina sp. yang masing-masing diperkaya minyak ikan, kuning telur ayam, dan pakan buatan telah diuji pengaruhnya terhadap pertumbuhan dan sintasan benih ikan betutu. Percobaan dilakukan dalam wadah toples plastik yang berisi air $7 \mathrm{~L}$, dilengkapi aerasi dengan dasar wadah dilubangi dan dipasang plankton net. Wadah percobaan disusun secara seri dalam bak fiber gelas $(2 \mathrm{~m} \times 1,2 \mathrm{~m} \times 0,5 \mathrm{~m})$ yang telah diisi air setinggi $0,4 \mathrm{~m}$. Pada fiber gelas dipasang pemanas air (heather) hingga kisaran suhu $28^{\circ} \mathrm{C}-30^{\circ} \mathrm{C}$. Di atas wadah percobaan dipasang pipa yang berfungsi mensuplai air, dan air mengalir keluar dari bagian bawah sehingga terjadi sirkulasi air dalam wadah percobaan. Padat tebar ikan uji adalah 5 ekor/L benih umur 25 hari. Sebagai perlakuan adalah pakan alami; (a) Moina sp. dan nauplii Artemia (50\%:50\%), (b) Moina sp. (100\%) diperkaya minyak ikan, (c) Moina sp. (100\%) diperkaya minyak ikan dan tepung telur ayam, (d) Moina sp. (100\%) dan diperkaya minyak ikan dan pakan buatan. Percobaan dilaksanakan dengan Rancangan Acak Lengkap, dan masing-masing perlakuan dengan tiga ulangan. Hasil penelitian menunjukkan bahwa ikan uji yang diberi pakan Moina sp. diperkaya dengan minyak ikan dan pakan buatan memperlihatkan pertumbuhan bobot yang nyata lebih tinggi dari perlakuan lainnya $(\mathrm{P}<0.05)$, namun sintasannya lebih rendah. Sedangkan pertumbuhan bobot ikan uji maupun sintasan pada ketiga perlakuan lainnya tidak memperlihatkan perbedaan. Dapat disimpulkan bahwa pakan alami Moina sp. (100\%) diperkaya minyak ikan, kuning telur, dan pakan buatan cukup mendukung pertambahan bobot dan panjang tubuh benih betutu selama masa pemeliharaan, dan dapat menggantikan nauplii Artemia.
\end{abstract}

KATA KUNCl: betutu, pengkayaan, pakan alami

ABSTRACT: Improvement of fry production of marble goby (Oxyeleotris marmorata Blkr.) through feeding management using enriched natural food. By: Zafril Imran Azwar, Dewi Puspaningsih, and Imam Taufik

Four different combinations of dietary treatment of natural food (Moina sp. and Nauplii Artemia), and Moina sp. enriched with fish oil, chicken egg yolk and artificial feed were tested in feeding trials with the objective to study their effect on growth and survival rate of the fry of marble goby. The experiments were conducted using plastic jars as culture containers, each filled with $7 \mathrm{~L}$ of water with aeration and its perforated bottoms was covered with cloth of plankton net. The experimental jars were placed in one fiberglass tank filled with water provided with a heater to maintain the water temperature around $26^{\circ} \mathrm{C}$ to $30^{\circ} \mathrm{C}$. All of the experimental jars were arranged in one fiberglass tank supplied with water from the upper side and flowed through the bottom side, thus creating water circulation in the experimental jars. Fish fry of 25 days old 
were stocked into the experiment jars with stocking density of 5 fry/L. The dietary treatments tested were: (a) combination of Moina sp. and Artemia nauplii (50\%:50\%); (b) Moina sp. (100\%) enriched with fish oil; (c) Moina sp. (100\%) enriched with fish oil and chicken egg yolk; and (d) Moina sp. (100\%) enriched with fish oil and artificial feed. The experimental design used was the complete randomized design (CRD) with three replicates for each treatment. Results of the research indicated that the fry fed with Moina sp. enriched with fish oil and artificial feed increased body weight gain significantly higher $(P<0.05)$ than the other treatments but the survival rate was not significantly different than the others. In addition, body weight gain of the other three treatments were not significantly different from each other. It was concluded that the natural food, Moina sp. (100\%) enriched with fish oil, chicken egg yolk, and artificial feed considerably supported body weight and body length gain of the fry during the experimental period, which were 0.14-0.22 $\mathrm{g}$ and $2.20-2.28 \mathrm{~cm}$, respectively, with survival rates ranging from $43.33 \%$ to $70.00 \%$, and could be used to replace Artemia nauplii.

\section{KEYWORDS: marble goby, enrichement, natural food, feeding management}

\section{PENDAHULUAN}

Ikan betutu (Oxyeleotris marmorata Blkr), merupakan ikan kosumsi dari perairan tawar yang memiliki nilai ekonomis tinggi, baik untuk pasar dalam negeri maupun ekspor. Namun, hingga dewasa ini produksinya sebagian besar tergantung dari hasil di alam, baik sebagai ikan ukuran konsumsi maupun ikan ukuran benih untuk budidaya. Usaha budidaya sudah lama dikembangkan oleh masyarakat terutama yang memiliki potensi perairan umum seperti di wilayah Sumatera dan Kalimantan, namun kegiatan belum menuju ke usaha intensif, karena kekurangan atau belum ada informasi teknologi yang dapat menunjang usaha yang lebih maju. Di samping informasi teknologi budidaya, usaha pembenihan juga merupakan aspek yang perlu diperhatikan, mengingat selama ini untuk kegiatan budidaya ikan diperoleh dari hasil tangkapan di perairan umum. Umumnya masyarakat mulai membesarkan ikan pada ukuran 150-200 g/ind. Jarang atau belum ada masyarakat yang mengembangkan atau menyiapkan benih ikan untuk ukuran budidaya, melalui pemeliharaan bertahap (pembenihan, pendederan).

Beberapa penelitian aspek pembenihan telah dirintis mulai dari karakterisasi reproduksi (musim, tipe pemijahan, fekunditas) dan proses pematangan gonad, tipe substrat kolektor telur, jenis pakan induk, stimulasi ovulasi dengan hormonal, kebiasaan makan induk di alam, aspek biologi larva meliputi perkembangan dan kebiasaan makan larva secara alami, manajemen perawatan larva, meliputi nuansa warna lingkungan/wadah, penggunaan berbagai pakan alami, fotoperiode, dan lain-lain. (Azwar et al., 2004). Dari berbagai hasil penelitian ini, telah dicoba produksi massal benih dalam wadah terkontrol, namun masih memberikan hasil yang belum memuaskan, karena hasil yang diperoleh masih sangat bervariasi dengan sintasan hanya mencapai 0\%-20\% selama 21 hari pemeliharaan. Fase paling kritis terjadi pada usia baru menetas hingga larva umur 8 hari, yang disebabkan kesulitan penyediaan pakan alami yang sesuai. Untuk ukuran yang lebih besar umur 21 hari ke atas, tingkat kematian mulai menurun mencapai 20\%-30\%. Permasalahan umum yang ditemui pada umur ini adalah ketersediaan pakan yang layak dan cukup serta lingkungan, terutama suhu air. Apabila kedua faktor ini tidak diperhatikan ikan mudah stres, sakit, dan muncul kanibalisme. Pada pascalarva udang galah yang diberi pakan dengan Moina sp. yang kaya asam lemak, ternyata meningkatkan sintasan benih secara nyata (Das et al., 2007). Moina sp. (Zooplankton) kandungan lemak tubuhnya $98 \%$ tergantung dari pakan yang dimakannya, hanya sebagian kecil yang dapat disintesis oleh tubuh (Becker \& Boersma, 2005).

Hasil penelitian terdahulu dengan menggunakan pakan alami nauplii Moina sp. dan nauplii Artemia memperlihatkan bahwa, untuk benih umur 24 hari hingga 70 hari, substitusi Moina sp. terhadap nauplii Artemia dalam kombinasi 50\%:50\% menunjukkan pertumbuhan yang paling tinggi, dan penggunaan 
Moina sp. 100\% memperlihatkan pertumbuhan yang sangat nyata lebih rendah (Azwar et al., 2005), walaupun kandungan protein dan lemaknya relatif sama dengan nauplii Artemia (Watanabe \& Kiron, 1994). Penggunaan nauplii Artemia sebagai pakan sangat tidak ekonomis, Oleh karena itu, perlu dilakukan pergantian artemia dengan Moina sp. yang diperbaiki kualitasnya melalui metode pengkayaan pakan alami. Moina sp. sebagai hewan air tawar biasanya kaya asam lemak $n-6$, dan sedikit asam lemak n-3 namun mudah disediakan. Ketidakseimbangan asam lemak n-3/n6 akan mengurangi laju pertumbuhan ikan. Selain itu, juga pakan alami, umumnya sedikit mengandung mikro nutrien seperti vitamin dan mineral yang juga sangat berperan dalam pertumbuhan dan kesehatan benih.

Percobaan ini bertujuan untuk mengetahui pengaruh pengkayaan pakan alami Moina sp. terhadap pertumbuhan dan sintasan benih ikan betutu, sebagai upaya pengganti nauplii Artemia.

\section{BAHAN DAN METODE}

Ikan uji yang digunakan adalah benih betutu ukuran $0.07 \pm 0.006 \mathrm{~g}$, umur 25 hari dari menetas. Telur yang diperoleh dari pemijahan induk di kolam, ditetaskan dalam akuarium, kemudian larva dipelihara atau dibesarkan dalam akuarium ukuran 0,8 $\mathrm{m} \times 0,4 \mathrm{~m} \times 0,5 \mathrm{~m}$. Selama pemelihaan, ikan diberi pakan alami berbagai jenis yaitu: Choelastrum sp. dan Paramecium sp. hingga umur 8 hari, kemudian diberikan rotifer hingga umur 14 hari, setelah itu diberi pakan nauplii Artemia. Selama pemeliharaan suhu air dijaga dalam kisaran $28^{\circ} \mathrm{C}-29^{\circ} \mathrm{C}$.

Percobaan dilakukan dalam wadah/toples plastik volume $10 \mathrm{~L}$, dan diisi air sebanyak $7 \mathrm{~L}$. Sebagian dasar wadah dilubangi dan dipasang net yang berfungsi menimbulkan sirkulasi air pada saat penggantian air, dan dalam wadah percobaan dipasang aerasi dengan gelembung yang sangat kecil. Semua wadah percobaan diletakkan dalam wadah fiber gelas ukuran $2 \mathrm{~m} \times 1,20 \mathrm{~m}$, dan keting gian 0,5 m. Di atas masing-masing wadah dipasang pipa, yang berperan menyuplai air secara tetap ke dalam wadah. Wadah diletakkan/direndam dalam bak fiber gelas yang diisi air dan diberi pemanas air, agar suhu air dalam wadah percobaan/ toples tidak berfluktuasi lebar. Padat tebar ikan uji adalah 5 ekor/L benih umur 25 hari. Sebagai perlakuan adalah sebagai berikut:

\section{A. Pakan alami Moina sp. dan nauplii Artemia (50\%:50\%)}

B. Moina sp. (100\%) diperkaya minyak ikan

C. Moina sp. (100\%) diperkaya minyak ikan dan telur ayam

D. Moina sp. (100\%) diperkaya minyak ikan dan pakan buatan

Masing-masing perlakuan dilakukan dengan 3 ulangan, dengan Rancangan Acak Lengkap. Minyak ikan yang digunakan "scot emulsion" (komersial), pakan buatan produk fripak dengan ukuran butiran 5-20 $\mu \mathrm{m}$. Parameter yang diamati adalah sintasan, bobot, dan panjang badan dan parameter lingkungan yang meliputi amonia, nitrit, dan suhu air. Analisis air dilakukan dengan menggunakan kit analisis aquant (merck) 1,14428 (nitrit) dan 1,14408 (amonia) yang masing-masing kisaran nilai terukur 0,005-0,100 mg/L, dan 0,025$0,400 \mathrm{mg} / \mathrm{L}$.

Penyediaan pakan alami, Moina sp. dilakukan dengan mengkultur di kolam beton yang diberi pupuk kotoran ayam sebanyak $3.000 \mathrm{mg} / \mathrm{L}$. Setelah hari kedua belas sudah dapat dilakukan pemanenan Moina sp. Pemanenan dilakukan dengan menggunakan saringan bertahap yaitu pertama plankton net ukuran $400 \mu \mathrm{m}$, dan kemudian plankton net $200 \mu \mathrm{m}$. Moina sp. kemudian diletakkan dalam toples volume $5 \mathrm{~L}$, dihitung kepadatannya. Nauplii Artemia disediakan dengan menetaskan cyst Artemia pada wadah yang telah diisi air laut dan diberi aerasi. Kemudian 24-30 jam setelah diinkubasikan cyst akan menetas, dan dipanen dengan saringan nauplii, kemudian disimpan dalam toples volume $2 \mathrm{~L}$. Pakan alami diberikan masing-masing 3 kali untuk Moina sp. dan nauplii Artemia (pagi, siang, dan malam hari) mengikuti prosedur Amornsakun et al. (2003a). Pengkayaan Moina sp. dengan minyak ikan dan pakan tambahan lainnya mengikuti metode Watanabe (1988). Pakan alami dalam wadah percobaan diamati dan dihitung tiap pagi hari, dan kemudian ditambahkan kembali sesuai dengan perlakuan. Percobaan dilaksanakan selama 30 hari, sampling air dilakukan tiap 6 hari sekali, sedangkan bobot, panjang badan, serta jumlah ikan yang hidup dihitung pada akhir penelitian. Dilakukan juga analisis asam lemak dan asam amino pakan alami sebelum dan setelah diperkaya. 


\section{HASIL DAN BAHASAN}

Dari penelitian yang telah dilaksanakan selama 30 hari diperoleh hasil bobot dan panjang akhir ikan uji seperti tertera pada Tabel 1.

Pada Tabel 1 terlihat bahwa bobot akhir rata-rata ikan uji yang paling tinggi diperoleh pada perlakuan Moina sp. yang diperkaya minyak ikan dan pakan buatan (D), dari bobot awal rata-rata $0,07 \mathrm{~g}$ pada umur 24 hari, terjadi penambahan bobot sebesar $0,22 \mathrm{~g}$, sehingga bobot akhir menjadi 0,29 g pada umur 54 hari. Selanjutnya berturut-turut penambahan bobot yang cukup tinggi diperoleh pada perlakuan Moina sp. dan nauplii Artemia (50\%:50\%) (A) serta perlakuan Moina sp. yang diperkaya minyak ikan (B). Penambahan bobot paling rendah diperoleh pada perlakuan Moina sp. yang diperkaya minyak ikan dan tepung kuning telur. Kisaran bobot akhir ikan uji pada akhir penelitian antara 0,19-0,29 g.

Dari penelitian ini dapat terlihat bahwa, memperkaya atau melengkapi asam lemak pada Moina sp. melalui pemberian asam lemak spesifik dapat meningkatkan kualitas asam lemak, tercermin dari penambahan bobot ratarata (Tabel 1), kandungan asam lemak Moina sp. yang diperkaya (Tabel 2) dan tubuh ikan uji di akhir penelitian (Tabel 3). Penambahan bobot ikan pada perlakuan Moina sp. diperkaya minyak ikan dan pakan tambahan lainnya lebih baik dan dapat mengimbangi pertumbuhan pada perlakuan Moina sp. : nauplii Artemia (50:50\%). Penelitian Becker \& Boersma (2005) yang memperbaiki gizi Daphnia magna, spesies satu kelas dengan Moina sp., dengan menggunakan plankton Skeletonema obliquus sebagai pakan alami yang telah diperkaya satu jenis asam lemak (asam eicosanoic, C20:2, ESA; asam eicosatetraenoic, 20:5 $\Omega 3$, EPA) dengan perendaman selama 13 jam memperlihatkan adanya peningkatan asam-asam lemak tersebut pada Moina sp. uji. Penelitian Das et al. (2007) mencatat bahwa Moina sp. yang diperkaya dengan minyak ikan mengalami peningkatan asam lemak esensial eicosapentaenoic, EPA, dan docosahexaenoic DHA (HUFA) sangat nyata masing-masing mencapai 7,31\% dan 2,17\%. Kadar kedua senyawa tersebut pada kondisi Moina sp. tidak diperkaya adalah tidak terdeteksi (0) (Watanabe et al., 1983). Penelitian Ako et al. (1994) juga mencatat bahwa kandungan beberapa asam lemak esensial nauplii meningkat hampir 2 kali lipat setelah melalui proses pengkayaan. Hasil analisis asam lemak pada Moina sp. yang telah diperkaya minyak ikan dalam percobaan ini memperlihatkan peningkatan untuk kadar asam lemak linolenat

Tabel 1. Penambahan bobot dan panjang ikan betutu pada akhir penelitian

Table 1. Weight and length gain of betutu fry at the end of the experiment

\begin{tabular}{ccccc}
\hline $\begin{array}{c}\text { Perlakuan } \\
\text { Treatment }\end{array}$ & $\begin{array}{c}\text { Bobot akhir } \\
\text { Final body } \\
\text { weight } \\
\mathbf{( g )}\end{array}$ & $\begin{array}{c}\text { Penambahan } \\
\text { bobot } \\
\text { Weight gain } \\
\mathbf{( g )}\end{array}$ & $\begin{array}{c}\text { Panjang akhir } \\
\text { Final length } \\
(\mathbf{m m})\end{array}$ & $\begin{array}{c}\text { Penambahan } \\
\text { panjang } \\
\text { Length gain } \\
(\mathbf{m m})\end{array}$ \\
\hline A & 0.24 & $0.15^{\mathrm{a}}$ & 28.50 & $20.21^{\mathrm{a}}$ \\
B & 0.22 & $0.14^{\mathrm{a}}$ & 28.30 & $20.10^{\mathrm{a}}$ \\
C & 0.19 & $0.12^{\mathrm{a}}$ & 27.30 & $19.40^{\mathrm{a}}$ \\
D & 0.29 & $0.22^{\mathrm{b}}$ & 29.60 & $21.80^{\mathrm{a}}$ \\
\hline
\end{tabular}

Keterangan:

- Nilai dalam kolom yang sama dikuti huruf yang sama menunjukkan tidak berbeda nyata $(P<0,05)$

- A (Moina sp. dan nauplii Artemia 50\%:50\%); B (Moina sp. diperkaya minyak ikan); C (Moina sp. diperkaya minyak ikan dan telur ayam); D (Moina sp. diperkaya minyak ikan dan pakan buatan)

Note:

- Values in the same column followed by the same letter are not significantly different $(P>0.05)$

- A (Moina sp. and nauplii Artemia 50\%:50\%); B (Moina sp. enriched with fish oil); $C$ (Moina sp. enriched with fish oil and chicken egg); $D$ (Moina sp. enriched with fish oil and artificial feed) 
Tabel 2. Komposisi asam lemak pada Moina sp. yang diperkaya minyak ikan, telur ayam dan pakan buatan ( $\mathrm{g} / \mathrm{g}$ bb)

Table 2. Fatty acids profiles of Moina sp. enriched with fish oil, chicken egg yolk, and artificial feed $(g / g b b)$

\begin{tabular}{lcccc}
\hline \multirow{2}{*}{$\begin{array}{c}\text { Jenis asam lemak } \\
\text { Fatty acid profiles }\end{array}$} & \multicolumn{4}{c}{ Perlakuan (Treatments) } \\
\cline { 2 - 5 } & A & B & C & D \\
\hline Meristik (Meristic acid) $(14: 0)$ & 0.08 & 0.08 & 0.09 & 0.09 \\
Palmitat (Palmitate acid) $(16: 0)$ & 1.88 & 1.99 & 1.90 & 1.92 \\
Sterat (Stearic acid) $(18: 0)$ & 0.32 & 0.32 & 0.34 & 0.31 \\
Oleat (Oleic acid) $(18: 1 \Omega 9)$ & 2.62 & 2.44 & 2.56 & 2.60 \\
Linoleat (Linoleic acid) $(18: 2 \Omega$ 6) & 0.56 & 0.66 & 0.54 & 0.58 \\
Linolenat (Linolenic acid) $(18: 3 \Omega$ 3) & 0.00 & 1.81 & 1.61 & 1.51 \\
Arachidonate (Arachidinate acid) & 0.20 & 0.38 & 0.30 & 0.32 \\
EPA (Eicosapentaenoic) $(20: 5 \Omega 3)$ & 0.00 & 0.46 & 0.44 & 0.43 \\
DHA (Docosahexaenoic) $(22: 6 \Omega 3)$ & 0.00 & 0.90 & 0.40 & 0.40 \\
\hline
\end{tabular}

Keterangan:

- A (Moina sp. dan nauplii Artemia 50\%:50\%); B (Moina sp. diperkaya minyak ikan); C (Moina sp. diperkaya minyak ikan dan telur ayam); D (Moina sp. diperkaya minyak ikan dan pakan buatan) Note:

- A (Moina sp. and nauplii Artemia 50\%:50\%); B (Moina sp. enriched with fish oil); $C$ (Moina sp. enriched with fish oil and chicken egg); D (Moina sp. enriched with fish oil and artificial feed)

18:3 $\Omega 3$ ), eicosapentaenoic dan DHA. (Tabel 2). Penelitian Das et al. (2007) pada larva udang galah memperlihatkan bahwa pemberian Moina sp. yang diperkaya dengan minyak ikan memperlihatkan laju tumbuh spesifik yang paling tinggi yaitu mencapai 3,60 $\pm 0,02 \%$.

Kandungan EPA dan DHA pascalarva tubuh udang galah juga meningkat. EPA dalam pascalarva mencapai $7,82 \%$ sedangkan kontrol hanya mencapai $2,45 \%$. Hasil pengamatan terhadap asam lemak tubuh ikan uji juga meningkat, terutama untuk asam-asam lemak linolenat (18:3 $\Omega 3$ ), EPA dan DHA (Tabel 3). Asam-asam lemak esensial dari minyak ikan antara lain asam linolenat (18:3 $\Omega 3)$, EPA (20:5 $\Omega 3)$ dan docosahexaenoic DHA $(\mathrm{C} 22: 6 \Omega 3)$ masing-masing mengandung $0,49 \% ; 11,80 \%$; dan $9,93 \%$.

Di samping faktor asam-asam lemak, peningkatan tumbuh lebih baik pada perlakuan Moina sp. diperkaya dengan minyak ikan dan pakan buatan, kemungkinan disebabkan peningkatan kandungan asam-asam amino dan protein, karena pakan buatan yang digunakan spesifik untuk benih dengan kandungan asam amino sebanding dan cukup unsur mineral dan vitamin, walaupun data-data tersebut tidak diperoleh dari analisis. Asam-asam amino bebas, dimanfaatkan di samping pertumbuhan juga digunakan sebagai sumber energi bagi hewan akuatik (ikan) pada usia dini (Fyhn, 1989). Hal serupa disimpulkan oleh Ronnestad (1992) dalam Watanabe \& Kiron (1994), yang mengamati pada perkembangan ikan stadia awal, terutama pada saat perkembangan embrio, di mana dicatat bahwa asam amino bebas dari kuning telur sangat cepat menurun.

Penelitian sebelumnya juga mencatat bahwa pertumbuhan benih betutu umur yang sama yang diberi pakan Brachionus sp. dan Moina sp. berkisar antara 0,22-0,23 g, sehingga penambahan bobot sebesar $0,22 \mathrm{~g}$ masih dianggap normal. Histogram yang menggambarkan pertambahan bobot ikan uji selama masa pemeliharaan 30 hari dapat dilihat pada Gambar 1. Panjang akhir rata-rata ikan uji paling tinggi juga diperoleh pada perlakuan Moina sp. yang diperkaya minyak ikan dan pakan buatan, dari panjang awal rata-rata 7,8 $\mathrm{mm}$ pada usia 25 hari, terjadi penambahan panjang sebesar 21,8 $\mathrm{mm}$ menjadi $29,6 \mathrm{~mm}$ 
Tabel 3. Komposisi asam lemak tubuh ikan betutu pada akhir percobaan $(\mathrm{g} / \mathrm{g} \mathrm{bb})$ Table 3. Fatty acids profiles of betutu fry after reared for 30 days

\begin{tabular}{lcccc}
\hline \multirow{2}{*}{$\begin{array}{c}\text { Jenis asam lemak } \\
\text { Fatty acid profiles }\end{array}$} & \multicolumn{4}{c}{ Perlakuan (Treatments) } \\
\cline { 2 - 5 } & A & B & C & D \\
\hline Meristik (Meristic acid) $(14: 0)$ & 0.171 & 0.125 & 0.09 & 0.185 \\
Palmitat (Palmitate acid) $(16: 0)$ & 1.888 & 1.969 & 1.741 & 1.323 \\
Sterat (Stearic acid) $(18: 0)$ & 0.353 & 0.121 & 0.476 & 0.230 \\
Oleat (Oleic acid) $(18: 1 \Omega 9)$ & 1.775 & 2.195 & 2.910 & 2.415 \\
Linoleat (Linoleic acid) $(18: 2 \Omega 6)$ & 0.706 & 0.890 & 0.670 & 0.415 \\
Linolenat (Linolenic acid) $(18: 3 \Omega 3)$ & 0.115 & 0.411 & 0.238 & 0.285 \\
Arachidonate (Arachidinate acid) & 0.020 & 0.020 & 0.022 & 0.024 \\
EPA (Eicosapentaenoic) $(20: 5 \Omega 3)$ & 0.020 & 0.200 & 0.019 & 0.023 \\
DHA (Docosahexaenoic) $(22: 6 \Omega 3)$ & 0.010 & 0.014 & 0.011 & 0.013 \\
\hline
\end{tabular}

Keterangan:

- A (Moina sp. dan nauplii Artemia 50\%:50\%); B (Moina sp. diperkaya minyak ikan); C (Moina sp. diperkaya minyak ikan dan telur ayam); D (Moina sp. diperkaya minyak ikan dan pakan buatan) Note:

- A (Moina sp. and nauplii Artemia 50\%:50\%); B (Moina sp. enriched with fish oil); $C$ (Moina sp. enriched with fish oil and chicken egg); $D$ (Moina sp. enriched with fish oil and artificial feed)

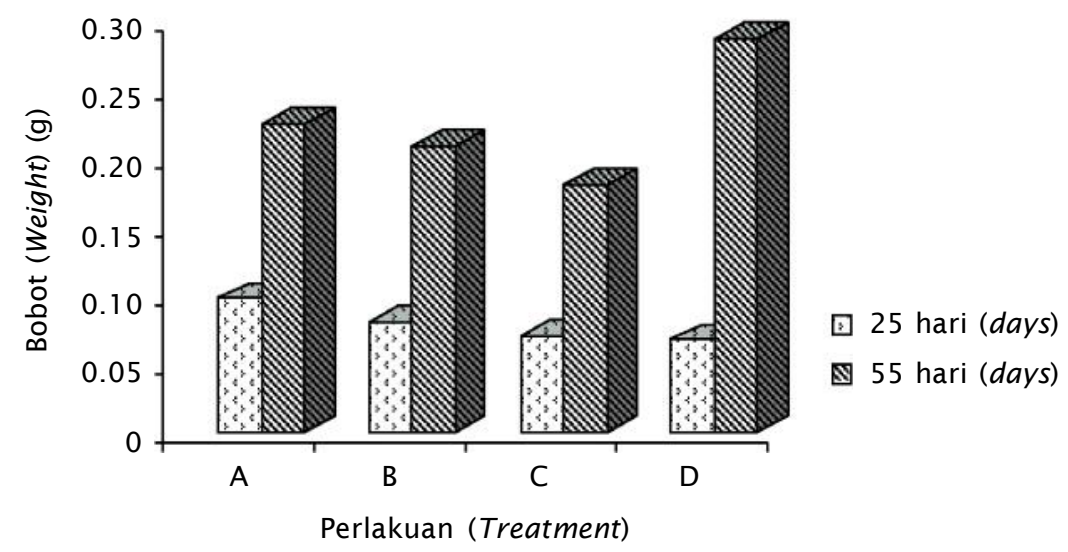

Keterangan:

- A (Moina sp. dan nauplii Artemia 50\%:50\%); B (Moina sp. diperkaya minyak ikan); C (Moina sp. diperkaya minyak ikan dan telur ayam); D (Moina sp. diperkaya minyak ikan dan pakan buatan)

Note:

- A (Moina sp. and nauplii Artemia 50\%:50\%); B (Moina sp. enriched with fish oil); C (Moina sp. enriched with fish oil and chicken egg); D (Moina sp. enriched with fish oil and artificial feed)

Gambar 1. Histogram pertambahan bobot ikan betutu selama pemeliharaan 30 hari

Figure 1. Histogram of marble goby fry weight gain after reared for 30 days 


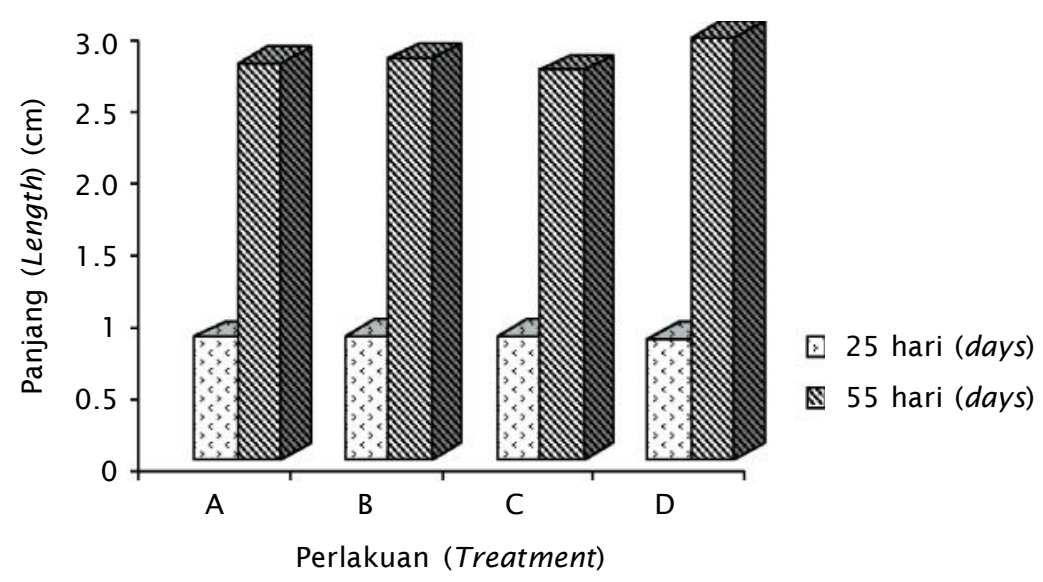

Keterangan:

- A (Moina sp. dan nauplii Artemia 50\%:50\%); B (Moina sp. diperkaya minyak ikan); C (Moina sp. diperkaya minyak ikan dan telur ayam); D (Moina sp. diperkaya minyak ikan dan pakan buatan)

Note:

- A (Moina sp. and nauplii Artemia 50\%:50\%); B (Moina sp. enriched with fish oil); C (Moina sp. enriched with fish oil and chicken egg); D (Moina sp. enriched with fish oil and artificial feed)

Gambar2. Histogram pertambahan panjang ikan betutu selama pemeliharaan 30 hari

Figure 2. Histogram of marble goby fry body length gain after reared for 30 days

pada umur 62 hari. Amornsakun et al. (2003b) berpendapat bahwa larva betutu umur 3-18 hari berukuran 3,1-4,1 mm; umur 21-27 hari berukuran 4,4-6,5 mm; dan umur 30-45 hari berukuran antara 6,9-21,5 mm; berarti ukuran ikan uji saat penelitian berakhir juga masih dapat dianggap normal yakni berkisar antara 27,3-29,6 mm (Tabel 1). Histogram yang menggambarkan pertambahan panjang ikan uji selama masa pemeliharaan 30 hari dapat dilihat pada Gambar 2.

Menurut Effendi (1997), pertumbuhan adalah pertambahan ukuran panjang atau bobot dalam suatu waktu. Di mana pertumbuhan merupakan proses biologi yang dipengaruhi oleh faktor luar dan dalam. Faktor yang umumnya sukar dikontrol adalah keturunan, seks, umur, parasit, dan penyakit. Sedangkan faktor luar yang utama mempengaruhi pertumbuhan adalah makanan dan suhu air. Dalam masa pemeliharaan larva ikan betutu, faktor makanan menjadi sangat penting karena ukuran larva serta bukaan mulutnya yang sangat kecil. Amornsakun et al. (2003a) menemukan bahwa bukaan mulut larva umur 3-18 hari antara 489,59-1376,88 m; umur 2127 hari antara 1558,93-2200,53 m, umur lebih dari 30 hari antara 2442,68-2850,20 m. Ukuran bukaan mulut yang sangat kecil ini membuat larva betutu sangat selektif dalam memakan makanannya. Selanjutnya hasil penelitian Azwar et al. (2005) juga menyebutkan bahwa umur larva 21-24 hari telah dapat memangsa Moina sp. dewasa.

Di akhir penelitian yakni setelah ikan uji mencapai umur 55 hari, sintasan benih betutu dengan perlakuan pemberian kombinasi Moina sp. dan nauplii Artemia (50\%:50\%) mencapai $70 \%$, lebih tinggi dibandingkan dengan perlakuan pemberian kombinasi Moina sp. diperkaya minyak ikan serta Moina sp. diperkaya minyak ikan dan tepung telur yang hanya $66,67 \%$. Sedangkan sintasan dengan perlakuan Moina sp. diperkaya minyak ikan dan pakan buatan paling rendah, yakni hanya mencapai 53,33\% (Tabel 4).

Dari Tabel 4 dapat dilihat bahwa perlakuan dengan kombinasi Moina sp. diperkaya minyak 
Tabel 4. Sintasan benih ikan betutu pada akhir penelitian

Table 4. Survival rate of betutu fry at the end of the experiment

\begin{tabular}{|c|c|}
\hline $\begin{array}{l}\text { Perlakuan } \\
\text { Treatments }\end{array}$ & $\begin{array}{c}\text { Sintasan } \\
\text { Survival rate (\%) }\end{array}$ \\
\hline A & $70.00 \pm 26.46^{a}$ \\
\hline B & $66.67 \pm 23.09^{a}$ \\
\hline $\mathrm{C}$ & $66.67 \pm 5.77^{\mathrm{a}}$ \\
\hline D & $53.33 \pm 20.82^{\mathrm{a}}$ \\
\hline \multicolumn{2}{|c|}{$\begin{array}{l}\text { Keterangan: } \\
\text { - Nilai dalam kolom yang sama dikuti huruf yang sama } \\
\text { menunjukkan tidak berbeda nyata }(\mathrm{P}<0,05) \\
\text { - A (Moina sp. dan nauplii Artemia } 50 \%: 50 \%) \text {; B (Moina sp. } \\
\text { diperkaya minyak ikan); C (Moina sp. diperkaya minyak } \\
\text { ikan dan telur ayam); D (Moina sp. diperkaya minyak ikan } \\
\text { dan pakan buatan) }\end{array}$} \\
\hline $\begin{array}{l}\text { Note: } \\
\text { - Values in the sam } \\
\text { not significantly } \\
\text { - A (Moina sp. and } \\
\text { enriched with fish } \\
\text { chicken egg); } D \text { (M } \\
\text { feed) }\end{array}$ & $\begin{array}{l}\text { owed by the same letter are } \\
\text { 05) } \\
\text { mia } 50 \%: 50 \% \text { ); B (Moina sp. } \\
\text { sp.enriched with fish oil and } \\
\text { hed with fish oil and artificial }\end{array}$ \\
\hline
\end{tabular}

ikan dan pakan buatan mempunyai sintasan yang paling rendah dibandingkan dengan perlakuan lainnya, namun memiliki pertambahan bobot dan panjang yang paling tinggi. Tidak terlihat gangguan terhadap kesehatan ikan dan kematian karena cenderung adanya sifat kanibalisme yang tinggi dari ikan betutu. Menurut beberapa penelitian yang telah dilakukan yang berhubungan dengan sifat kanibalisme menjelaskan bahwa sifat kanibalisme disebabkan oleh adanya perbedaan ukuran ikan dan faktor ketidakcukupan tersediaan pakan (Folkvord, 1997). Dalam semua perlakuan terjadi perbedaan ukuran ikan uji yang meyebabkan terjadinya pemangsaan sehingga sintasan sangat bervariasi. Ketersediaan pakan tidak merupakan faktor utama terjadinya kanibalisme dalam percobaan ini karena ketersediaan pakan sangat mencukupi, dilihat dari masih ditemui pakan alami setiap pengamatan pada pagi dan malam hari pada masing-masing wadah percobaan. Menurut Hepher \& Pruginin (1984), daya dukung lingkungan dari suatu wadah pemeliharaan adalah jumlah ikan maksimum pada ukuran tertentu yang dapat ditampung oleh wadah tersebut tanpa menggangu kesehatan maupun pertumbuhan. Daya dukung lingkungan budidaya dalam sistem akuakultur terkontrol sangat dibatasi oleh kandungan oksigen dan amonia $\left(\mathrm{NH}_{3}\right)$ (Meade, 1985 dalam Grommen et al., 2002). Dalam percobaan ini parameter amonia pada masing-masing perlakuan masih dalam kisaran normal untuk pertumbuhan, sedangkan oksigen walaupun tidak terukur tidak menjadi faktor pembatas karena sistem wadah pemeliharaan mendapat suplai oksigen (aerasi) dan penggantian air yang teratur. Dalam kondisi cukup pakan pada semua perlakuan dan kondisi kualitas air yang sangat mendukung (Tabel 5) telah menyakinkan bahwa pertumbuhan lebih baik pada perlakuan dengan kombinasi Moina sp. diperkaya minyak ikan dan pakan buatan berkaitan dengan kualitas pakan yang diberikan.

Hasil analisis statistik menunjukkan bahwa penambahan bobot ikan betutu uji berbeda nyata $(P<0,05)$ antara perlakuan $D$ dan perlakuan $A, B$, dan $C$; namun tidak diikuti dengan perbedaan pertambahan panjang $(P>0,05)$ (Tabel 1). Demikian pula halnya dengan sintasan yang ternyata tidak berbeda nyata antara perlakuan $(P>0,05)$, meskipun 
Tabel 5. Kisaran kualitas air (amonia, nitrit, dan suhu) selama percobaan

Table 5. Range of water quality (ammonia, nitrite, and temperature) during the experiment

\begin{tabular}{|c|c|c|c|}
\hline \multirow{2}{*}{$\begin{array}{l}\text { Perlakuan } \\
\text { Treatments }\end{array}$} & \multicolumn{3}{|c|}{ Parameter kualit as air (Water quality parameters) } \\
\hline & $\begin{array}{c}\text { Amonia (Ammonia) } \\
(\mathrm{mg} / \mathrm{L})\end{array}$ & $\begin{array}{c}\text { Nit rit (Nit rite) } \\
(\mathrm{mg} / \mathrm{L})\end{array}$ & $\begin{array}{c}\text { Suhu (Temperat ure) } \\
\left({ }^{\circ} \mathrm{C}\right)\end{array}$ \\
\hline A & $0.10-0.25$ & $0.10-0.35$ & $28-31$ \\
\hline B & $0.025-0.25$ & $0.15-0.30$ & $28-31$ \\
\hline $\mathrm{C}$ & $0.05-0.30$ & $0.05-0.30$ & $28-31$ \\
\hline $\mathrm{D}$ & $0.15-0.25$ & $0.10-0.30$ & $28-31$ \\
\hline
\end{tabular}

Keterangan:

- A (Moina sp. dan nauplii Artemia 50\%:50\%); B (Moina sp. diperkaya minyak ikan); C (Moina sp. diperkaya minyak ikan dan telur ayam); D (Moina sp. diperkaya minyak ikan dan pakan buatan)

Note:

- A (Moina sp. and nauplii Artemia 50\%:50\%); B (Moina sp. enriched with fish oil); C (Moina sp. enriched with fish oil and chicken egg); D (Moina sp. enriched with fish oil and artificial feed)

sintasan tertinggi dicapai oleh perlakuan pemberian kombinasi Moina sp. dan nauplii Artemia (50\%:50\%). Penelitian Fermin (1991) menyebutkan bahwa sintasan dan pertumbuhan ikan laut "sea bass" Lates calcarifer ukuran fry terbaik jika ikan diberi pakan campuran Moina sp. dan nauplii Artemia. Penelitian Das et al. (2007) memperlihatkan bahwa sintasan pascalarva udang galah yang diberi pakan Moina sp. diperkaya dengan minyak ikan nyata lebih tinggi dibandingkan yang diberi pakan tanpa diperkaya. Pendapat yang serupa dikemukakan oleh Ako et al. (1994), dari hasil penelitiannya pada larva Mungil cephalus, bahwa stres fisik dapat dikurangi jika larva disiapkan dengan pakan alami (nauplii Artemia) yang diperkaya. Rendahnya sintasan benih pada perlakuan Moina sp. diperkaya dengan minyak ikan dan pakan buatan, lebih cenderung disebabkan pemangsaan dalam masa percobaan.

Pengamatan kualitas air dalam media selama masa pemeliharaan 30 hari tidak memperlihatkan nilai yang membahayakan bagi perkembangan ikan (Tabel 5).

Hasil pengukuran kualitas air yang mencakup amonia, nitrit, dan suhu air selama masa pemeliharaan menunjukkan bahwa kisarannya masih baik untuk budidaya. Kadar amonia masih di bawah $1 \mathrm{mg} / \mathrm{L}$ (Boyd, 1980).
Di samping kualitas gizi meningkat, ukuran Moina sp. relatif lebih besar dari nauplii Artemia. Menurut Lim et al. (2003), ukuran pakan alami harus dipertimbangkan disesuaikan dengan ukuran ikan, ukuran pakan terlalu kecil menyebabkan ikan akan membutuhkan waktu lebih lama mencapai kenyang, dan akan menghasilkan pertumbuhan yang tidak baik karena tidak efisiensi dan banyak membuang energi.

\section{KESIMPULAN}

Penggunaan Artemia sebagai pakan benih ikan betutu pada umur lebih dari 25 hari sudah dapat digantikan dengan Moina sp. 100\% yang diperkaya dengan minyak ikan, atau minyak ikan dan telur, atau minyak ikan dengan pakan buatan (fripak).

\section{DAFTAR ACUAN}

Ako, H., Tamaru, C.S., Bass, P., \& Cheng Seng Lie. 1994. Enchanching the resistance to physical strees in larvae of Mungil cephalus by the feeding of enriched artemia nauplii. Aquaculture, 122: 81-90.

Amornsakun, T.W., Sriwatana, \& Chamnanwech, U. 2003a. The culture of sand goby, Oxyeleotris marmoratus I: Feed and feeding scheme of larvae and juveniles. Songklanakarin J. Sci. Technol., 25(3): 367-371. 
Amornsakun, T.W., Sriwatana, \& Chamnanwech, U. 2003b. The culture of sand goby, Oxyeleotris marmoratus II: Gastric emptying times and feed requirements of larvae. Songklanakarin J. Sci. Technol., 25(3): 373379.

Azwar, Z.I., Priyadi, A., \& Sutrisno. 2005. Pengaruh pemberian pakan alami Moinasp. sebagai substitusi artemia dalam produksi massal benih ikan betutu ukuran fry. Laporan Hasil-Hasil Penelitian Tahun 2005. Balai Riset Perikanan Budidaya Air Tawar, Badan Riset Kelautan dan Perikanan, Departemen Kelautan dan Perikanan, 11 hlm.

Azwar, Z.I., Sutrisno, \& Taufik, P. 2004. Studi produksi benih ikan betutu dengan perbaikan mutu pakan induk. Balai Riset Perikanan Budidaya Air Tawar, Badan Riset Kelautan dan Perikanan, Departemen Kelautan dan Perikanan, hlm. 195-207.

Becker, C. \& Boersma, M. 2005. Differential effect of phosphorus and fatty acids on Daphnia magna growth and reproduction. Limnol. Oceanogr., 50(1): 388-397.

Boyd, C.E. 1980. Water quality in warm water fish ponds. Auburn University. Agricultural Experiment Station. Auburn University, Alabama, p. 73-125.

Das, S.K., Tiwari, V.K., Venkateshwarlu, G., Reddy, A.K., Parhi, J., Sharma, P., \& Cheitri, J.K. 2007. Growth, survival and fatty acid composition of Macrobrachium rosenbergii (de Man), 1879 (post larva) fed HUFA-enriched Moina micrur. J. Aquaculture, 269(1-4): 464475.

Effendie, M.I. 1997. Biologi Perikanan. Yayasan Pustaka Nusatama, Yogyakarta, 163 hlm.
Fermin, A.C. 1991. Freshwater cladoceran, Moina macropoda (Straus) as an alternative livefood for rearing sea bass Lates calcarifer (Bloch) fry. J. Appl. Ichthyol., 7: 8-14.

Fyhn, H.J. 1989. First feeding of marine fish larvae: Are free amino acids the source of energy. Aquaculture, 80: 111-120.

Folkvord, A. 1997. Ontogeny of Cannibalism in larva and juvenile Fishes with Special Emphasis on Atlantic Cod. In: Chambers, R.C., Trippel, E.A. (Eds.), Early Life History and Recuirement in Fish Populations. Chapman \& Hall, London, p. 251-278.

Grommen, R., Hauteghem, I.V., Wambeke, M.V., \& Verstraete, W. 2002. An Improved Nitrifying Enrichment to Remove Ammonium and Nitrite from Freshwater Aquaria Systems. Elsivier. Aquacultural Engineering, 211: 115-124.

Hepher, B. \& Pruginin, Y. 1984. Commercial Fish Farming. John Willey and Sons, New York, $261 \mathrm{pp}$.

Lim, L.C., Dhert, P., \& Sorgeloss, P. 2003. Recent developments in the application of live feeds in the fresh water ornamental fish culture. Aquaculture, 227: 319-331.

Watanabe, T., Kitajima, C., \& Fujita, S. 1983. Nutritional values of live organisms used in Japan for mass propagation of fish:Review. Aquaculture, 34: 115-143.

Watanabe, T. 1988. Fish nutrition and mariculture JICA. The general aquaculture course. Dept of agriculture bioscience, Tokyo University, $233 \mathrm{pp}$.

Watanabe, T. \& Kiron, V. 1994. Prospects in larvae fish dietetics. Aquaculture, 124: 223251. 